\section{A CASE OF ABSCESS OF THE LUNG CURED BY INCISION AND DRAINAGE.}

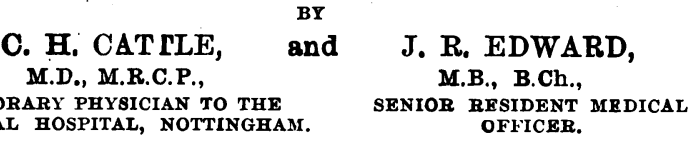

HONORARY PHYBICIAN TO THE
GENERAL HOSPITAL, NOTTINGHAM. OFFICER.

THE difficulties which may be experlenced in locating an abscess deeply placed within the chest, and the comparative rarity of complete success in the treatment of this condition, seem to us aufficlent reasons for placing the lollowing case on record.

W. S., aged 36, previously strong and healthy, was taken ill in July, 1907. He was engaged on night duty in a brewery, and besides having very hard work was exposed to sudden changes of temperature. There was no evidence of excessiva Indulgence in alcohol. His illness commenced gradually with cough and weakness. Afterwards he had several shivering attacks, with pain in the back, shortness of breath, and covgh. He was inow attended by Dr. Hill of Old Basford, who informs us he detected signs of pleuro-pnenmonis, followed by effusion into the left pleura. This disappesred, but, after the patient had been laid up seven weeks, ne began to expectorate large had been laid up seven weeks, ne began to expectorate large
quantities of plnkish tenacious spusum, which afierwards assumed the appesrance of ordinsry pos. Notwithstaoding this, he attempted to get about, but suffered from psin, with swelling of the legs and feet, also from cough and shortness of breath.

He was admitted into the Nottingham General Hospital on September 18 th, having been 111 over two months. Ha was pale and wasted; mucous membranes of good colour. Weight 8 st., which speedily declined to 7 st. 11 lb., at "which it remsined with slight varlation Palse 124, regular, low tension. Resplrations 28 Tho Palse 124, regular, low tension. Resplrations 28
temperature was hectic, rangIng from 980 to $101^{\circ}$ or 102\%. The spatam continued coplous antil the date of the operation (December 14th), consisting of inodorous, thin, frothy pas, the quantity varying from 4 to $18 \mathrm{cz}$. An examination for tubercle bacllil was negative. The patient always $\in$ Xpressed himself as feeling comfortable, but was obliged to lie in a very constralned position-vamely, on the right side, with the bead near the edge of the bed. Doubtless this facilitated drainage of the cavity, since any attempt to lle on the back or left side cared uncontrollable cough.

Physical Signs.

Heart: The apex beat could not be seen or felt. The sounds were normal, and the organ was not displaced. Lungs (left side): Movement impaired; deficlent resonauce over the whole of the left lung, most marked at the lower part of the axille, and near the angle of the scapuls. Breath sounds everywhere weak, especlally below the angle of the scapala, although vocal resonence was present in this position. At the apex; below the nipple; and near the angle of the scapula, the breath sounds were distant and bronchisl. There were scattered, small crepitations all over the left side, whlch were of somewhat amphorio quality, though distant, at the lower anterlor region. Right Lung : Blight dallness over the epex. and a few crepitations, these signs not boing nearly 80 marked as at the corresponding - region on the left side. [It was thought at one time that general pyogenis infection of both lungs had occurred, bat the subsequent progress of the case makes it probable that the signs in the right side were caused by pus conveyed from the left side, partly in conseguence of the peculiar decubitus adopted, and partly by ssplration. ]

an exploring needle was inserted into the duli ares near the
An left base. soon after the man's admisslon, with negative result. No further attempt to reach the pas was made for tbree months. In the. meantime the patient was treated by tonics, sedatives, and antiseptlcs, both by ingestion and inhalation. From thesg he derived no benefit, and was obviously gettlng worse when, on Decomber 10th. the exploring needle was again used, and a syringeful of pas obtained.

\section{Operation.}

On December 14th the patient was placed nnder the influence of chloroform, and sfter several frultless attempts pas was again found by the needle, inserted deeply a litte below the angle of the left scapule. Af incision in this region, a plece of the eighth rib was exclsed. incision in this region, a plece of the eighth rib was exclsed.
The pleural cavity was found to bo obliterated, and the The pleural cavity was found to be obliterated, and the pleura. Renewed difficulty now arose in finding the pas, as the needle had been removed during the resection of the rib. After searching in various directions it wa suggested that the needle should be passed downwards and forwards, and this resalted in success jast when wo had almost decided to give up the attempt, pus being found at a depth of $2 \frac{1}{2}$ in. from the surface. A pair of dressing forceps was now $2 \frac{1}{2}$ in. from the surface. A pait of dressing forceps was now with the utmost diffculty, owing to the toughness of the lang tissio. The treok thus formed was enlerged by using the rib forceps in the same manner, it being thought. ungafe to use a knife ander the circumstances. Pus now welled up from the bottom of the wound. The above manlpulations excited a violent fit of coughing, and, if any proof were needed that we were really working in the lung, this was afforded by the exwere really working in the lung, this was afforded by the expectoration of blood, mixed with pus, and by the free passage
of air through the wound. The tip of the forefinger inserted into the wound just entered a small cevity, probsbly communicating with a larger one, for on tarning the patient on to his back about half a pint of blood-atained pus escaped. $\Delta$ rubber tabe, of $\frac{1}{2}$ in. bore and long enough to reach the bottom of the wound, was inserted, and \& wood-wool dressing applied.

The after-history of the patient was very satisfactory. On the afternoon of the operation day he felt comfortable, and had coughed ap traces of blood in the sputam. During the next fow days the expectoration rapidly diminished to an ounce or two, and the pulmonary fistala gradually closed, although the to and fro passage of air durlng respiration was very free at first. The wound healed rapldly. On January 5th, 1908, ganze packing was substituted for the tube, and by the 20 th healing was completed by the formation of a sound scar parallel with the ribs, about $2 \frac{1}{2}$ in. long. By this date also cough and expectoration had quite ceased. Resonance was good over both lungs, except at the base of the left lung behind and in the lower part of the axllis. In the same regions the and in the lower part of the axila. In the same regions the breath sounds were feeble and accompanied by fine dry plearal were normal, and the morement good. The man's aspect and physique had greatly altered for the better. He was discharged quite well on January $25 \mathrm{th}, 1908$, and sent to a convalescen lome, his weight heing 9 st. $5 \frac{1}{4} \mathrm{lb}$, , having put on $22 \frac{1}{4} \mathrm{lb}$. since December $14 \mathrm{th}$. When seen on February 19th, the patient expressed himself as feeling very well, having gained a fartber $10 \mathrm{lb}$.

The opinion is very generally held that uncomplicated creupous pneumonla occasionally ends in abscess of the lung. It is probable, however, that this is a rarer occurrence than is commonly supposed. This is the oplnion of Dr. Pge.Smith, and also of the gre st Laënnec, whom he quotes as tollows": "Il n'a pas de lésion organlque plus rare qu'une véritable collection de pus dans le tissu pulmonalre." Although this patlent presented the slgns of abscess of the lung when he came under our notice, it does not follow that the cavity was formed by the actual solution of hepatized lung. While this may be, not Improbably, the partial explanation, there may also have been a locallzed empyema, which by dlscharging through the lung may have Increased the amount of purulent dlscharge. The pus was not fetid, hence there is no reason to suspect gangrene of the lung or bronchiectasis. The dally amonnt of pus expectorated (10 onnces or more) left little doubt In our minds that it came from a cavlty of considerable size. Yet signs of cavity were for the most part wanting. Instead of loud gurgling and amphoric sounds, as might have been expected, we could only find distant crepltations, and weak tubular breathing. The fibroid thlckening of the tissues and the depth of the abscess doubtless accounted for the obscurity of the slgns.

We would draw attention to the Inability of the abscess to heal, notwithstanding free exit to the pus by expectoration, and to the rapidity of healing aiter drainage through a dependent opening. The sound clcatrization of the tissues and closing of the bronchial fistula are also worthy of note. A fistuls in such circumstances is apt to remain permanent-especially in tuberculous and bronchlectatic cases. $^{2}$

1 Allbutt's System, vol. v, p. 112 . West, Diseares of the Organs of Respiration, p. 645 .

\section{A CASE OF PHLEGMONOUS GASTRITIS.}

BY

ARTHUR J. HALL, and GRAHAM SIMPSON, M.A., M.D.Centab., F.R.C.P.,

LECTURER ON PRACTICAL SHEFFIELD ; $\triangle$ SSISTANT
SURGEON, SHEFFIRLD ROTA ROYAL HOSPITAL.

Phurgmosous gastritis is happlly one of the rarer diseases affecting the stomach; its exact diagnosis is difficult and ite prognosis grave. In recording this case we add one to the list of published cases in which a short history of symptoms is followed by an account of the post mortem findings.

There are two features of this case to which we would call attention, first, that the probable source of infection was the mouth, and that it followed the extraction of many teeth; secondly, the presence of an ergthematous 